\title{
Preoperative AST/ALT (De Ritis) Ratio as a Prognostic Factor in a Cohort of Patients who underwent radical cystectomy
}

\section{Radikal sistektomi uygulanan hastalarda preoperatif AST/ALT (De Ritis) oranlarının prognostik önemi}

\author{
Kaan Gökç̧en ${ }^{1}$, Emrre Kuraç ${ }^{1}$, Punar Gö kçen ${ }^{2}$, Resul Çiçek ${ }^{1}$, Gökhan Gökçe
}

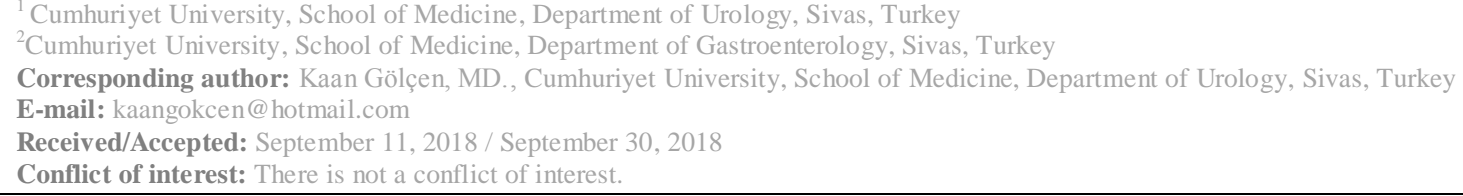

\section{SUMMARY}

Objective: This study aims to evaluate the prognostic significance of the preoperative aspartate aminotransferase (AST) / alanine aminotransferase (ALT) (De Ritis) ratio in bladder cancer (BC) patients who underwent radical cystectomy (RC).

Method: We evaluated the clinical and histopathological data of 58 patients who had undergone RC between January 2008-August 2018 at our tertiary hospital. The potential prognostic value of the De Ritis ratio with regard to BC was evaluated using ROC curve analysis. The effect of the De Ritis ratio on disease specific survival (DSS) and overall survival (OS) was analyzed using the Kaplan-Meier method and multivariate Cox regression models.

Results: A total of fifty-eight patients underwent RC and 95.6\% were male (M/F:56/2). Mean age of the patients was $68.6 \pm 11,56$. The cut-off value of the De Ritis ratio for DSS was calculated as 1.417 in the ROC analysis. In KaplanMeier analyses, the group with a higher De Ritis ratio presented a more unfavorable progression in terms of DSS and OS ( $\mathrm{p}=0.004)$. Based on the Cox regression models adjusted for clinical and pathological parameters, for DSS, the De Ritis ratio (HR 2.70, 95\% CI 2.34-3.05 p=0.005), pathological T stage (HR 3.36, 95\% CI 2.91-3.82, p =0.007), and age (HR 1,038 95\% CI 1,02-1,05; p=0.015) were determined as independent prognostic factors; and for OS, the De Ritis ratio (HR 2.71, 95\% CI $2.33-3.09 ; \mathrm{p}=0.005)$, pathological T stage (HR 4.36, 95\% CI 3.87-4.85; p=0.007) and age (HR $1.04,95 \%$ CI 1.03-1.06; $\mathrm{p}=0.015)$ were determined as independent prognostic factors.

Conclusions: A higher preoperative De Ritis ratio can be considered as an independent prognostic factor in BC patients who underwent RC. Our results need to be confirmed and corroborated by comprehensive prospective randomized studies with an appropriate design.

Keywords: Aminotransferases, bladder cancer, radical cystectomy, survival 
Bulgular: RC uygulanan toplamda ellisekiz hastanın 95.6\% erkek (E/K:56/2) idi. Hastaların yaş ortalaması 68.6 11,56 idi. ROC analizine göre DSS için De Ritis oranının cut-off değeri 1.417 olarak saptandı. Kaplan-Meier analizlerinde yüksek De Ritis oran grubu DSS ve OAS'de daha kötü progresyon gösterdi $(\mathrm{p}=0.004)$. Klinik ve patolojik parametrelerin Cox regresyon modellerinde DSS için De Ritis oranı (HR 2.70, 95\% CI 2.34-3.05 p=0.005), patolojik T evresi (HR 3.36, 95\% CI 2.91-3.82, p =0.007) ve yaş (HR 1,038 95\% CI 1,02-1,05; $\mathrm{p=0.015)}$ iken OAS için De Ritis oranı (HR 2.71, 95\% CI $2.33-3.09$; $\mathrm{p}=0.005$ ), patolojik T evresi (HR 4.36, 95\% CI 3.87-4.85; $\mathrm{p}=0.007$ ) ve yaş (HR $1.04,95 \%$ CI 1.03-1.06; $\mathrm{p}=0.015$ ) bağımsız prognostik faktörler olarak belirlendi.

Sonuç: Preoperatif artmış De Ritis oranı; RC uygulanan BC hastalarında bağımsız bir prognostik faktör olarak değerlendirilebilir. Sonuçlarımızın geniş ve uygun şekilde tasarlanmış prospektif, randomize çalışmalarla doğrulanması ve desteklenmesi gerekmektedir

Anahtar sözcükler: Aminotransferazlar, mesane kanseri ,radikal sistektomi, sağkalım

\section{INTRODUCTION}

Being four times more prevalent in males, bladder cancer (BC); is the seventh most common type of cancer in males worldwide and ranks eleventh when both sexes are considered (1). Nearly $75 \%$ of $\mathrm{BC}$ cases are confined to the mucosa with a high prevalence (Ta, carsinoma insitu [CIS], T1) and have lower cancer-specific mortality compared to invasive cases (T2-T4) (2). Although the prognosis of muscle invasive bladder cancers (MIBC) varies depending on the tumor stage and lymph node involvement, radical cystectomy (RC) is considered the standard treatment for localized MIBC $(3,4)$. It is known that $10-15 \%$ of MIBCs diagnosed today are metastatic at the time of diagnosis (5). Early cystectomy is also recommended for non-muscle invasive bladder cancers (NMIBC) with a high risk of progression (6).

Aspartate aminotransferase (AST) and alanine aminotransferase (ALT), which are used as biomarkers in the follow-up of hepatocellular functions and diseases based on the fact that they are released into the circulation from liver cells, are synthesized both by malignant and nonmalignant cells (7). The AST/ALT ratio (De Ritis ratio) used in cases of viral hepatitis by Fernando De Ritis in 1957 was later considered a low-cost prognostic factor with an easy use that could be utilized in cases of hepatic, non-hepatic diseases and malignancies (8). Previous studies have established the significance of the De Ritis ratio for many non-urological malignancies $(9,10)$. Studies on the prognostic significance of the De Ritis ratio for urological cancers, particularly upper tract urothelial carcinomas and renal cell carcinomas, can be found in the literature (11-13). In this study we aimed to evaluate the prognostic significance of the preoperative De Ritis ratio on survival in $\mathrm{BC}$ patients who underwent $\mathrm{RC}$ at our center.

\section{MATERIAL AND METHODS}

Clinical and histopathological data of 58 patients who had been diagnosed with $\mathrm{BC}$ and underwent $\mathrm{RC}$ at the department of Urology at Cumhuriyet University Hospital between January 2008 and August 2018 were obtained from the electronic database and evaluated retrospectively. Patients who discontinued follow-up or presented irregularly, had known liver diseases or other concurrent malignancies were excluded from the study. Except for two patients who had massive hematuria, all patients underwent RC approximately six weeks after transurethral resection of bladder tumor (TUR-BT). AST and ALT levels were obtained by the standard method one-week pre-operatively. The upper reference value for AST and ALT was defined as $40 \mathrm{U} / \mathrm{L}$. In the histopathological evaluation of patients who underwent RC, tumor stage, grade, lymphovascular invasion (LVI), and lymph node involvement were recorded. Causes of mortality were also obtained from the hospital database and investigated carefully.

Disease specific survival (DSS) was defined as the time between the date of surgery to the date of disease specific death, whereas overall survival (OS) was defined as time between the date of surgery to the date of death due to any cause. The optimal prognostic value to be determined for the De Ritis ratio to reveal its effect on survival was determined by obtaining a cut-off value by receiver operating characteristic curve (ROC) analysis. The associated sensitivity, specificity, positive predictive value, and negative predictive value were also determined. Nonparametric chisquare and Mann-Whitney $U$ tests were used to evaluate the relationship between the preoperative De Ritis ratio and histopathological parameters. 
To calculate the optimal AST/ALT cutoff by using receiver operating characteristic (ROC) curve analysis to differentiate patient survival and death. A multivariate Cox proportional regression analysis was performed to reveal the effect of age, pathological T stage, tumor grade, LVI and lymph node involvement, and preoperative AST/ALT on DSS and OS. Statistical analyses were done using the SPSS software demo version 22. Visual (histograms, probability plots) and analytical methods (Kolmogorov-Smirnov) were used in the evaluation of all variables to demonstrate whether or not they had a normal distribution. Descriptive analyses were presented in the form of means $( \pm \mathrm{SD})$ and medians (min-max). A p-value $<0.05$ was considered significant.

\section{RESULTS}

Fifty-six of the patients in our study were male (95.6\%) and the overall mean age was $68.6 \pm 11,56$ (27-84). None of the patients included in the study had undergone neoadjuvant chemotherapy. The histopathological evaluation of patients who had undergone $\mathrm{RC}$ revealed that the most common pathological T stage was T2 (43.1\%) and the most common grade was G3 (67.3\%). Thirty (51.7\%) patients presented lymphovascular invasion $(+)$ and twenty-four (41.4\%) lymph node involvement. Mean AST and ALT levels were respectively determined as 25,72 $\pm 21,56$ and $19,29 \pm 16,29$ U / L. Demographic, clinical, and laboratory parameters of the patients have been summarized in Table 1.

Table 1: Demographic and clinical properties of the patients

\begin{tabular}{|l|l|}
\hline Age $($ mean \pm Std) years (min-max) & $68.6 \pm 11,56(27-84)$ \\
\hline Sex $\mathrm{n}(\%)$ & \\
\hline fale & $56(96.6)$ \\
\hline female & $2(3.4)$ \\
\hline Lymphovascular Invasion $\mathrm{n}(\%)$ & \\
\hline positive & $30(51.7)$ \\
\hline negative & $28(48.3)$ \\
\hline T stage $\mathrm{n}(\%)$ & \\
\hline T0 & 0 \\
\hline T1 & $10(17.3)$ \\
\hline T2 & $25(43.1)$ \\
\hline T3 & $18(31.1)$ \\
\hline T4 & $5(8.6)$ \\
\hline Tumor Grade $\mathrm{n}(\%)$ & \\
\hline G1 & $5(8.6)$ \\
\hline G2 & $14(24.1)$ \\
\hline G3 & $39(67.3)$ \\
\hline Lymph node involvement $\mathrm{n}(\%)$ & \\
\hline positive & $24(41.4)$ \\
\hline negative & $34(58.6)$ \\
\hline AST (mean \pm Std) $(\min -\max )$ & $25,72 \pm 21,56$ \\
\hline ALT (mean \pm Std)(min-max) & $19,29 \pm 16,29$ \\
\hline AST/ALT (mean \pm Std) & $1,44 \pm 0,54$ \\
\hline
\end{tabular}


According to the ROC analysis performed to determine the prognostic diagnostic value of the De Ritis ratio for DSS, the area under the curve (AUC) was found as 0,854 (95\% CI ?????? $\mathrm{p}=0.011)$. The cut-off value of AST/ALT for DSS was determined as 1.417 , and the associated sensitivity and specificity were determined as $80 \%$ and $37 \%$, respectively (Figure 1 ).

\section{ROC Curve}

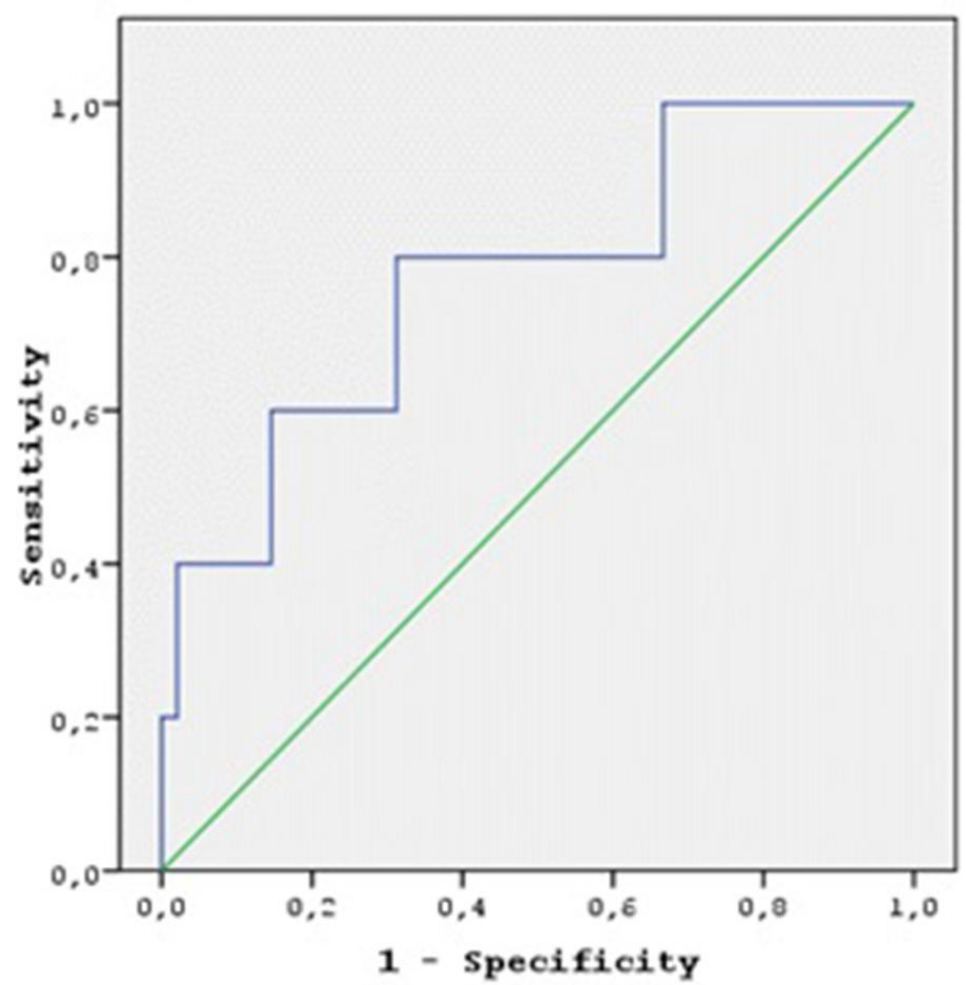

Figure 1: Receiver operating characteristic analysis of preoperative De Ritis ratio for DSS

The patient group with a De Ritis ratio higher than the determined cut-off value had a more unfavorable prognosis in terms of DSS and OS based on the Kaplan-Meier analysis $(\mathrm{p}=0.009$, $\mathrm{p}=0.004$ ) (Figure 2). Twenty-nine patients in the
DSS group had a De Ritis ratio below 1.417, whereas twenty-four patients had a De Ritis ratio above 1.417. In the OS group, thirty-one patients had a De Ritis ratio below 1.417 and twenty-seven had a De Ritis ratio above 1.417. 


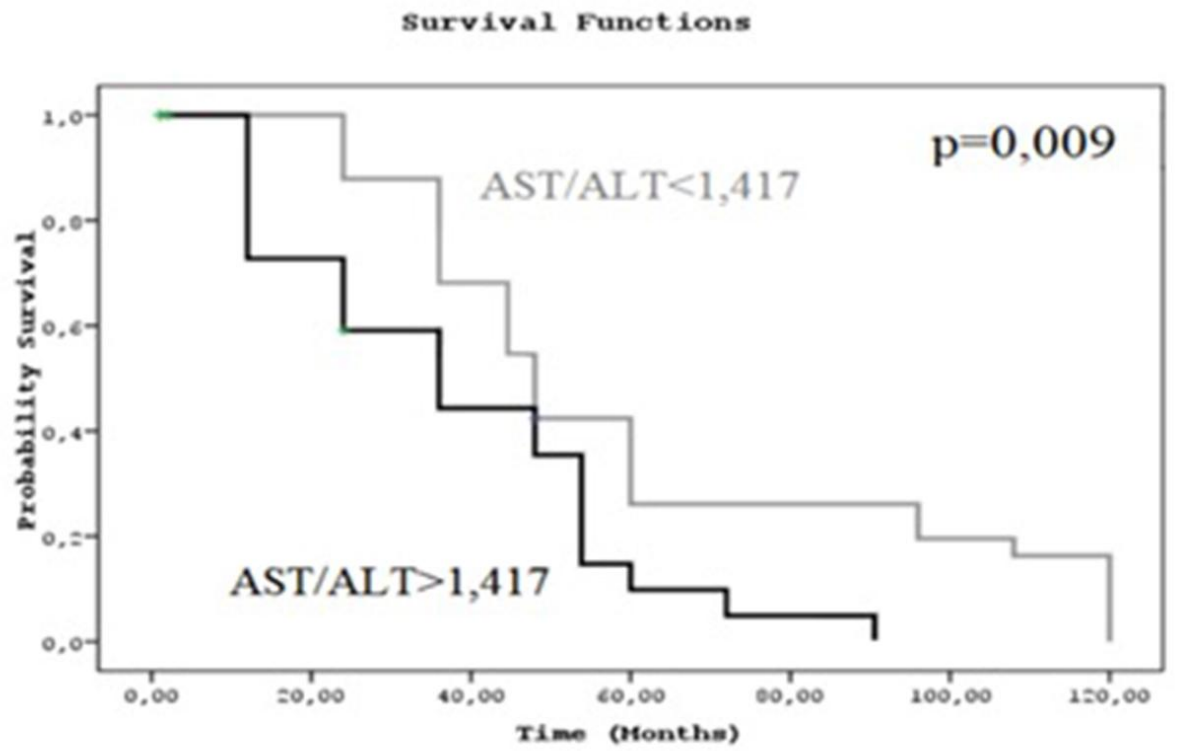

Figure 2: Kaplan-Meier analysis of disease-specific survival according to De Ritis ratio after cystectomy for bladder cancer

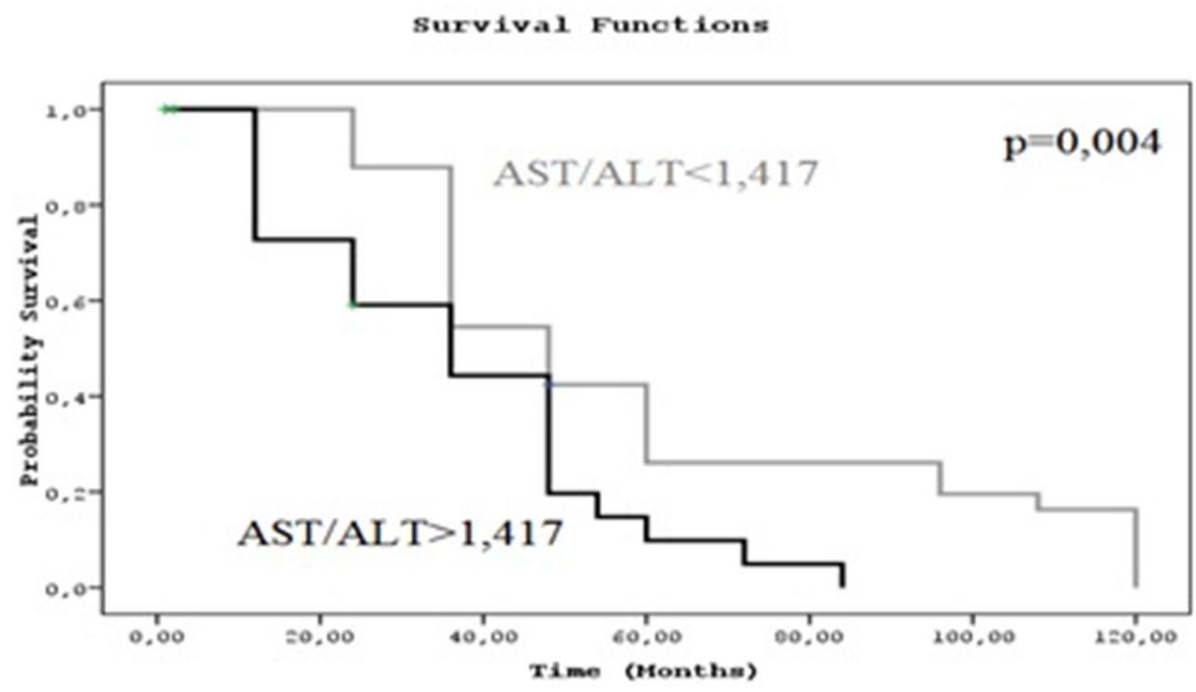

Figure 3: Kaplan-Meier analysis of overall survival according to De Ritis ratio after cystectomy for bladder cancer

Based on the multivariate Cox regression models of clinical and pathological parameters used to predict DSS, the De Ritis ratio (HR 2.70, 95\% CI 2.34-3.05 $\mathrm{p}=0.005)$, pathological $\mathrm{T}$ stage (HR $3.36,95 \%$ CI $2.91-3.82, \mathrm{p}=0.007)$, and age (HR $1,038 \quad 95 \%$ CI $1,02-1,05 ; \quad \mathrm{p}=0.015)$ were determined as independent prognostic factors; and for OS, the De Ritis ratio (HR 2.71, 95\% CI 2.33 3.09; $\mathrm{p}=0.005$ ), pathological $\mathrm{T}$ stage (HR 4.36, 95\% CI 3.87-4.85; $\mathrm{p}=0.007)$ and age (HR 1.04, 95\% CI 1.03-1.06; $\mathrm{p}=0.015)$ were determined as independent prognostic factors. 
Table 2: Multivariate Cox analysis of clinicopathological parameters for DSS and OS

\begin{tabular}{|c|c|c|c|c|}
\hline & \multicolumn{2}{|l|}{ DSS } & \multicolumn{2}{|l|}{ OAS } \\
\hline & HR $(95 \% \mathrm{CI})$ & $\mathrm{p}$ & HR $(95 \% \mathrm{CI})$ & $\mathrm{p}$ \\
\hline Age & $1,038(1,023-1,053)$ & $0,015^{*}$ & $1,049(1,033-1,065)$ & $0,015^{*}$ \\
\hline \multicolumn{5}{|l|}{$\begin{array}{l}\text { Lymphovascular } \\
\text { invasion }\end{array}$} \\
\hline Negative & 1 (reference) & & 1 (reference) & \\
\hline Positive & $1,838(1,415-2,251)$ & 0,141 & $2,045(1,611-2,479)$ & 0,141 \\
\hline $\begin{array}{l}\text { Pathological T Stage } \\
T 1-T 2 \\
T 3-T 4\end{array}$ & $\begin{array}{l}1 \text { (reference) } \\
3,367(2,914-3,820)\end{array}$ & $0,007 *$ & $\begin{array}{l}1 \text { (reference) } \\
4,367(3,878-4,856)\end{array}$ & $0,007 *$ \\
\hline $\begin{array}{l}\text { Tumor Grade } \\
\text { G1 } \\
G 2-G 3\end{array}$ & $\begin{array}{l}1 \text { (reference) } \\
1,065(0,541-1,589)\end{array}$ & 0,905 & $\begin{array}{l}1 \text { (reference) } \\
1,054(0,520-1,588)\end{array}$ & 0,905 \\
\hline $\begin{array}{l}\text { Lymph node involvement } \\
\text { Negative } \\
\text { Positive }\end{array}$ & $\begin{array}{l}1 \text { (reference) } \\
1,580(1,192-1,968)\end{array}$ & 0,238 & $\begin{array}{l}1 \text { (reference) } \\
1,695(1,282-2,108)\end{array}$ & 0,238 \\
\hline $\begin{array}{l}\text { AST/ALT } \\
\text { Below } 1.41 \\
\text { Above } 1.41 \\
\end{array}$ & $\begin{array}{l}1 \text { (reference) } \\
2,703(2,348-3,058)\end{array}$ & $0,005^{*}$ & $\begin{array}{l}1 \text { (reference) } \\
2,710(2,330-3,090)\end{array}$ & $0,005^{*}$ \\
\hline
\end{tabular}

\section{DISCUSSION}

AST and ALT, which are two transaminases released by hepatocytes, are commonly being used in the diagnosis and follow-up of liver diseases and hepatocellular carcinoma. The AST/ALT ratio defined years ago has been used to determine the prognosis in viral hepatitisrelated hepatocellular carcinoma (14). While ALT is predominantly a liver-specific enzyme, AST is expressed by various tissues (7). As AST increases more than ALT in cases of increased proliferation speed, tissue damage, and tumor cell cycle, the De Ritis ratio is considered to indicate systemic changes such as tumor proliferation (15). Along with studies that suggest increased AST levels are a significant prognostic factor in determining liver metastases of malignancies, the De Ritis ratio was also found to be higher in cancers without liver metastasis and this ratio was determined to return to normal following definitive treatment $(16,17)$. The AST/ALT ratio that is predicted to be an independent prognostic factor has been investigated in connection to various types of cancer over time (18-20). The prognostic role of the De Ritis ratio was demonstrated by studies investigating urological cancers, particularly by studies of RCCs and upper tract urothelial carcinomas (11-13, 21). Similarly, a study done on prostate cancer stated that the De Ritis rate affected prognosis and played a predictive role with regard to biochemical recurrence alongside the Gleason score (22).

It has been known that the glucose metabolism is involved in the pathogenesis of urothelial carcinomas $(23,24)$. Tumoral cells may prefer anaerobic glycolysis as it provides ATP more easily and rapidly compared to oxidative phosphorylation. It is known that proliferative tumor cells also perform aerobic glycolysis to ensure the metabolization of glutamine and the synthesis of necessary nucleotides and amino acids with the help of AST and ALT (25). Tumor cells can multiply with the ATP made available by increased glycolysis. While the relationship between urothelial carcinomas, which are glucosedependent malignancies, and the AST/ALT ratio is not completely clear, AST transports NADH, which plays an important role in the breakdown of glucose through the malate-aspartate shuttle, into the mitochondria (26). Lactate dehydrogenase and $\mathrm{NADH} / \mathrm{NAD}+$ play a major role in glucose catabolism (27). 
While there is no standard threshold value for the De Ritis ratio in the literature, previous urological studies have conducted their analyses using values in the 1.26-1.50 range $(11,12,21,22,25)$. In our study, the threshold value was determined as 1.41 , paralleling other studies. Preoperative AST/ALT ratios above 1.41 were determined as a prognostic factor for both the DSS and OS groups. In a similar study that investigated RC patients, data obtained from 153 patients were analyzed to reveal a De Ritis ratio of 1.30 for DSS and OS, and similarly to our study, it was emphasized that a high AST/ALT ratio was an independent prognostic factor for both groups (28). This study also found that age and tumor stage accompanied a high De Ritis rate as significant prognostic factors both for DSS and OS $(p<0.005)$. Based on these data, we predict that a high preoperative AST/ALT ratio is a significant and independent predictive factor for DSS and OS following radical surgery.

Today, many studies are being conducted to utilize molecular markers related to malignancies as prognostic factors to predict clinical results, however, this process is made complicated by factors such as the tissue-based nature of these markers, the need for a pathological specimen, and high cost. Recently, an increasing number of laboratory studies show interest in beneficial and easy to obtain factors such as the NLR (neutrophil/lymphocyte ratio) and De Ritis ratio that could have prognostic value.

Our study has certain limitations that can be primarily listed as the low number of patients in the study population, being limited to a single center, and having a retrospective design. We think that our results will be confirmed by prospective studies that will include a larger number of BC patients and monitor these preoperative ratios in the postoperative period as well.

\section{CONCLUSION}

An increased preoperative AST/ALT ratio was determined to accompany tumor stage as an unfavorable prognostic factor both for DSS and OS in patients who underwent RC. These findings need to be corroborated by studies with a larger sample size.

\section{REFERENCES}

1. Ferlay J, Steliarova-Foucher E, LortetTieulent J, Rosso S, Coebergh JWW, Comber $\mathrm{H}$, et al. Cancer incidence and mortality patterns in Europe: Estimates for 40 countries in 2012. Eur J Cancer. 2013; 49(6):1374-403.

2. Burger M, Catto JWF, Dalbagni G, Grossman HB, Herr H, Karakiewicz P, et al. Epidemiology and Risk Factors of Urothelial Bladder Cancer. Eur Urol. 2013; 63(2):234-41.

3. Stein JP, Lieskovsky G, Cote R, Groshen S, Feng AC, Boyd S, et al. Radical cystectomy in the treatment of invasive bladder cancer: long-term results in 1,054 patients. J Clin Oncol. 2001; 19(3):66675.

4. Jewett HJ. Proceedings: Cancer of the bladder. Diagnosis and staging. Cancer. 1973]; 32(5):1072-4.

5. ROSENBERG J, CARROLL P, SMALL E. UPDATE ON CHEMOTHERAPY FOR ADVANCED BLADDER CANCER. J Urol. 2005; 174(1):14-20.

6. Herr HW, Sogani PC. Does early cystectomy improve the survival of patients with high risk superficial bladder tumors? J Urol. 2001; 166(4):1296-9.

7. Botros M, Sikaris KA. The De Ritis Ratio: The Test of Time. Vol. 34, Clin Biochem Rev. 2013; 34(3):117-30

8. DE RITIS F, COLTORTI M, GIUSTI G. An enzymic test for the diagnosis of viral hepatitis; the transaminase serum activities. Clin Chim Acta. 1957; 2(1):704.

9. Thornburg JM, Nelson KK, Clem BF, Lane AN, Arumugam S, Simmons A, et al. Targeting aspartate aminotransferase in breast cancer. Breast Cancer Res. 2008; 10(5):R84.

10. Stocken DD, Hassan AB, Altman DG, Billingham LJ, Bramhall SR, Johnson PJ, et al. Modelling prognostic factors in advanced pancreatic cancer. Br J Cancer. 2008; 99(6):883-93.

11. Nishikawa M, Miyake H, Fujisawa M. De Ritis (aspartate transaminase/alanine transaminase) ratio as a significant predictor of recurrence-free survival in patients with upper urinary tract urothelial carcinoma following nephroureterectomy. Urol Oncol. 2016; 34(9):417.e9-417.e15.

12. Bezan A, Mrsic E, Krieger D, Stojakovic 
T, Pummer K, Zigeuner R, et al. The Preoperative AST/ALT (De Ritis) Ratio Represents a Poor Prognostic Factor in a Cohort of Patients with Nonmetastatic Renal Cell Carcinoma. J Urol. 2015; 194(1):30-5.

13. Lee H, Lee SE, Byun S-S, Kim HH, Kwak C, Hong SK. De Ritis ratio (aspartate transaminase/alanine transaminase ratio) as a significant prognostic factor after surgical treatment in patients with clear-cell localized renal cell carcinoma: a propensity scorematched study. BJU Int. 2017; 119(2):261-7.

14. Poon RT, Fan ST, Lo CM, Liu CL, Ng IO, Wong J. Long-term prognosis after resection of hepatocellular carcinoma associated with hepatitis B-related cirrhosis. J Clin Oncol. 2000; 18(5):1094101.

15. Zoppini G, Cacciatori V, Negri C, Stoico V, Lippi G, Targher G, et al. The aspartate aminotransferase-to-alanine aminotransferase ratio predicts all-cause and cardiovascular mortality in patients with type 2 diabetes. Medicine (Baltimore). 2016 Oct; 95(43):e4821.

16. O'Reilly SM, Richards MA, Rubens RD. Liver metastases from breast cancer: the relationship between clinical, biochemical and pathological features and survival. Eur J Cancer . 1990; 26(5):574-7.

17. Chougule A, Hussain S, Agarwal DP. Prognostic and diagnostic value of serum pseudocholinesterase, serum aspartate transaminase, and serum alinine transaminase in malignancies treated by radiotherapy. J Cancer Res Ther. 2008; 4(1):21-5.

18. Tan X, Xiao K, Liu W, Chang S, Zhang T, Tang H. Prognostic factors of distal cholangiocarcinoma after curative surgery: a series of 84 cases. Hepatogastroenterology. 2013; 60(128):1892-5.

19. Takenaka $\mathrm{Y}$, Takemoto $\mathrm{N}$, Yasui $\mathrm{T}$, Yamamoto $\mathrm{Y}$, Uno A, Miyabe $\mathrm{H}$, et al. Transaminase Activity Predicts Survival in Patients with Head and Neck Cancer. Langevin SM, editor. PLoS One. 2016; 11(10):e0164057.

20. Chen S-L, Li J-P, Li L-F, Zeng T, He X.
Elevated Preoperative Serum Alanine Aminotransferase/Aspartate

Aminotransferase (ALT/AST) Ratio Is Associated with Better Prognosis in Patients Undergoing Curative Treatment for Gastric Adenocarcinoma. Int J Mol Sci. 2016; 917(6):911. doi: 10.3390/ijms17060911.

21. Lee H, Choi YH, Sung HH, Han DH, Jeon HG, Chang Jeong B, et al. De Ritis Ratio (AST/ALT) as a Significant Prognostic Factor in Patients With Upper Tract Urothelial Cancer Treated With Surgery. Clin Genitourin Cancer. 2017 Jun;15(3):e379-85.

22. Wang H, Fang K, Zhang J, Jiang Y, Wang $\mathrm{G}$, Zhang $\mathrm{H}$, et al. The significance of De Ritis (aspartate transaminase/alanine transaminase) ratio in predicting pathological outcomes and prognosis in localized prostate cancer patients. Int Urol Nephrol. 2017; 49(8):1391-8.

23. Tai Y-S, Chen C-H, Huang C-Y, Tai H-C, Wang S-M, Pu Y-S. Diabetes mellitus with poor glycemic control increases bladder cancer recurrence risk in patients with upper urinary tract urothelial carcinoma. Diabetes Metab Res Rev. 2015 Mar; 31(3):307-14.

24. Whyard T, Waltzer WC, Waltzer D, Romanov V. Metabolic alterations in bladder cancer: applications for cancer imaging. Exp Cell Res. 2016 Feb 1;341(1):77-83.

25. DeBerardinis RJ, Mancuso A, Daikhin E, Nissim I, Yudkoff M, Wehrli S, et al. Beyond aerobic glycolysis: transformed cells can engage in glutamine metabolism that exceeds the requirement for protein and nucleotide synthesis. Proc Natl Acad Sci USA . 2007 Dec 4;104(49): 19345-50.

26. Greenhouse W V, Lehninger AL. Occurrence of the malate-aspartate shuttle in various tumor types. Cancer Res. 1976 Apr; 36(4):1392-6.

27. Fantin VR, St-Pierre J, Leder P. Attenuation of LDH-A expression uncovers a link between glycolysis, mitochondrial physiology, and tumor maintenance. Cancer Cell. 2006 Jun; 9(6):425-34.

28. Gorgel SN, Kose O, Koc EM, Ates E, Akin Y, Yilmaz Y. The prognostic 
significance of preoperatively assessed AST/ALT (De Ritis) ratio on survival in patients underwent radical cystectomy. Int Urol Nephrol [Internet]. 2017 Sep; 49(9):1577-83. 